\title{
Phakopsora pachyrhizi in vitro sensitivity to fungicides*
}

\author{
Marta Maria Casa Blum ${ }^{1}$ e Erlei Melo Reis ${ }^{2}$
}

${ }^{1}$ Universidade Regional Integrada do Alto Uruguai e das Missões - URI, Campus de Erechim, RS. ${ }^{2}$ Universidade de Passo Fundo - UPF, Passo Fundo, RS. Bolsista CNPq. *Parte da tese de doutorado da primeira autora

Autor pata correspondência: Erlei Melo Reis (erleireis@upf.br)

Data de chegada: 03/01/2013. Aceito para publicação em: 10/07/2013.

Chemical control of Asian soybean rust (ASR), caused by Phakopsora pachyrhizi Syd. \& Syd., has been the most efficient tactic for its epidemic management, maintaining the yield, reducing damages, and keeping the sustainability of the soybean crop (3).

In vitro assays, to determine the fungitoxicity of a chemical, can be used for biotrophic pathogens; however, in most cases they are limited to the assessment of spore germination, germ tube growth or germ tube morphology (Pontzen, R.; Scheinpflug, H. , Torgeson, D. C. and Russel, P. E.).

The aim of this study was to determine, in vitro, the inhibitory concentration $\left(\mathrm{IC}_{50}\right)$ of the fungicides QoI [Quinone outside inhibitors (strobilurins)] and DMI [demethylation inhibitors (triazoles)] for a sensitive $P$. pachyrhizi isolate.

The used $P$. pachyrhizi inoculum was from a uredospore population collected from naturally infected soybean plants in the 2004/05 growing cycle in Passo Fundo (Rio Grande do Sul State, Brazil), hereafter called "sensitive isolate".

The $\mathrm{IC}_{50}$ for P. pachyrhizi was determined by using commercial formulations at the following concentrations (active ingredient): azoxystrobin $\left(0,0.005,0.05,0.5\right.$ and $\left.5 \mathrm{mg} . \mathrm{L}^{-1}\right)$, picoxystrobin and pyraclostrobin $\left(0,0.001,0.01,0.1,1\right.$ and $\left.5 \mathrm{mg} . \mathrm{L}^{-1}\right)$, trifloxystrobin $(0$, $0.001,0.01,0.1$ and $\left.1 \mathrm{mg} . \mathrm{L}^{-1}\right)$, cyproconazole $(0,0.5,2.5,5,10$ and 20 mg. $\left.\mathrm{L}^{-1}\right)$, epoxiconazole $\left(0,0.005,0.05,0.5,2.5\right.$ and $\left.5 \mathrm{mg} . \mathrm{L}^{-1}\right)$, flutriafol $\left(0,0.05,0.5,5\right.$ and $\left.25 \mathrm{mg} . \mathrm{L}^{-1}\right)$, metconazole $(0,0.005,0.05,0.5,2.5$ and $\left.5 \mathrm{mg} . \mathrm{L}^{-1}\right)$, myclobutanil $\left(0,0.5,1,2,4\right.$ and $\left.8 \mathrm{mg} . \mathrm{L}^{-1}\right)$, tebuconazole $\left(0,0.0025,0.005,0.01,0.02,0.05\right.$ and $\left.0.5 \mathrm{mg} . \mathrm{L}^{-1}\right)$, and tetraconazole $\left(0,2,4,5,10,20\right.$ and $\left.40 \mathrm{mg} . \mathrm{L}^{-1}\right)$. A spore suspension was adjusted to $2 \times 10^{3}$ uredospores. $\mathrm{mL}^{-1}$ and $350 \mu \mathrm{L} /$ dish was dispensed onto the substrate amended with the fungicides. The dishes were incubated in a Biological Oxygen Demand (BOD) chamber, at $22^{\circ} \mathrm{C}$, for six hours of exposure in the absence of light. Germination was determined under an optical microscope by scanning the dish surface. The $\mathrm{IC}_{50}$ was estimated based on the probit procedure using SAS statistical software, version 8.0 (Lopes, I. O. N. et al. ) (Table 1).

The spore germination method has limitations, especially concerning its correlation with responses obtained with fungal mycelial growth in the culture medium in in vivo tests. Another limitation is related to the fungicide, more specifically to the activation or not of the fungal target for the fungicide at time of spore germination (Pontzen, R.), e.g., DMIs. It is important to learn when the ergosterol synthesis starts or if the fungus uses its own ergosterol reserves at the moment of fungicide application. Clarkson et al. quantified in vitro the effect of propiconazole on Puccinia allii Rud. uredospore germination over a 24-hour period of exposure to the fungicide and reported that, at the concentrations of 0.1 and $0.075 \mathrm{mg} . \mathrm{L}^{-1}$, germination was inhibited by $100 \%$. Buck and Williams-Woodward and Clarkson et al. evaluated in vitro the efficacy of seven fungicides to Puccinia hemerocallidis
Table 1. In vitro concentration (mg. $\mathrm{L}^{-1}$ ) for QoI and IDM fungicides to inhibit 50\% ( $\left(\mathrm{IC}_{50}\right)$ Phakopsora pachyrhizi spores germination and germ tube length (Water-agar; $22{ }^{\circ} \mathrm{C}$; six hours exposure time under dark)

\begin{tabular}{llc}
\hline \multirow{2}{*}{ Fungicide } & \multicolumn{2}{c}{ IC $_{\mathbf{5 0}}$} \\
\cline { 2 - 3 } & Spore germination (\%) & Germ tube length $(\boldsymbol{\mu} \mathbf{m})$ \\
\hline QoI & \\
Azoxystrobin & $0.07^{*}$ & 0.02 \\
Picoxystrobin & 0.04 & 0.005 \\
Pyraclostrobin & 0.075 & 0.005 \\
Trifloxystrobin & 0.015 & 0.011 \\
DMI & & \\
Cyproconazole & $3.0^{*}$ & 26.46 \\
Epoxiconazole & 0.45 & - \\
Flutriafol & 5.61 & 11.98 \\
Metconazole & 0.44 & 3.36 \\
Myclobutanil & 3.07 & 0.05 \\
Tebuconazole & 0.0065 & 17.33 \\
Tetraconazole & 7.44 & \\
\hline
\end{tabular}

(*) Means of two experiments, estimated by Probit procedure.

Thümen and observed no reduction in uredospore germination when the fungicides propiconazole and myclobutanil were used at the tested concentrations, suggesting that the fungus probably uses its ergosterol reserves during the germination process, compromising thus the response obtained in in vitro tests. The exposure time of uredospores to fungicides in this test was 24 hours.

In our tests conducted for both spore germination and germ tube length using all triazole fungicides, the $\mathrm{IC}_{50}$ values were generated after six hours of uredospore exposure to fungicides. For myclobutanil and tebuconazole, $100 \%$ uredospore germination inhibition was found within only six hours of exposure. For myclobutanil and flutriafol, 99.1\% germination inhibition was detected; for tetraconazole, $99.0 \%$; for ciproconazole, $98.1 \%$; and for epoxiconazole, $98.0 \%$, probably not reaching $100 \%$ inhibition depending on the maximum concentrations used in the test.

It is likely that: (i) the fungus $P$. pachyrhizi synthesizes ergosterol within six hours after the beginning of in vitro exposure of uredospores to the fungicide; (ii) the mechanism of action of the tested DMIs in the first six hours after the beginning of in vitro exposure of $P$. pachyrhizi uredospores is not only on the synthesis of ergosterol (ergosterol is not synthesize so early); (iii) the adjuvants present in the commercial formulations of cyproconazole, epoxiconazole, flutriafol, metconazole, myclobutanil, tebuconazole and tetraconazole may have in vitro fungicidal or fungistatic effect on uredospore 
germination and germ tube growth.

A different behavior was observed for the tested chemical groups of fungicides (DMIs and QoIs). A wider range of $\mathrm{IC}_{50}$ values was observed for the group of DMIs and a narrower range for QoI.

$\mathrm{IC}_{50}$ values for $P$. pachyrhizi uredospore germination were higher than the $\mathrm{IC}_{50}$ values for germ tube length, considering the QoI fungicide group. $\mathrm{IC}_{50}$ values for $P$. pachyrhizi uredospore germination were lower than those for germ tube length considering triazole fungicides.
In vitro determination of the effect of fungicides on P. pachyrhizi provides results in a shorter period of time (less than $24 \mathrm{~h}$ ) with cost reduction, compared to in vivo experiments.

The $\mathrm{IC}_{50}$ values determined in this study can be used as a baseline for tracking $P$. pachyrhizi in vitro sensitivity to the fungicides azoxystrobin, picoxystrobin, pyraclostrobin, trifloxystrobin, cyproconazole, epoxiconazole, flutriafol, metconazole, myclobutanil, tebuconazole and tetraconazole in soybean. 